\title{
Pulmonary versus Extrapulmonary Acute Respiratory Distress Syndrome: Clinical Characteristics and Outcome
}

\author{
ABDALLAH S. AYOUB, M.D.*; AHMED H. WAHBA, M.D.* and ABDELMAABOUD M.M. OMAR, M.D.** \\ The Departments of Chest Diseases* and Clinical Pathology**, Faculty of Medicine, Al-Azhar University, Egypt
}

\begin{abstract}
Background: Acute respiratory distress syndrome is a clinical syndrome characterized by a refractory hypoxemia due to an inflammatory and high permeability pulmonary edema secondary to direct or indirect lung insult (pulmonary and extrapulmonary form). These two categories of ARDS patients are different regarding the respiratory mechanics, lung recruitment, gas exchange, and positive end-expiratory pressure response.
\end{abstract}

Aim of Study: The aim of this work was to compare the clinical characteristics and outcomes between the two major ARDS subtypes; pulmonary and extrapulmonary.

Patients and Methods: A prospective study was conducted during the period from July 2014 to January 2016 in Intensive Care Unit, El-Hussein University Hospital. It included 60 patients diagnosed as ARDS. They were subclassified into pulmonary and extrapulmonary ARDS groups according to the cause of lung injury. Both groups were compared regarding the clinical features, response to treatment and clinical outcome.

Results: Patients with extrapulmonary ARDS developed more deteriorated liver and renal functions and arterial blood gases with a better response to elevated levels of PEEP and vasopressors with a mortality rate of $75 \%$. In patients with pulmonary ARDS, mild organs dysfunction were developed with a better response to low levels of PEEP and a mortality rate of $25 \%$.

Conclusion: Subdivision of ARDS into pulmonary and extrapulmonary categories has worthy effect on both treatment and clinical outcome. Additionally, they are different in the degree of organ dysfunction and severity of clinical pictures.

Recommendation: Proper assessment of patients with ARDS at admission to put them within a major category whether pulmonary or extrapulmonary ARDS. This simple classification will help physician to decide on treatment and to predict prognosis.

Key Words: Pulmonary ARDS - Extrapulmonary ARDS Acute lung injury - Intensive care unit.

Correspondence to: Dr. Abdallah S. Ayoub, The Department of Chest Diseases, Faculty of Medicine, Al-Azhar University, Egypt

\section{Introduction}

ARDS, the more severe form of Acute Lung Injury (ALI), is a common and fetal disease in the critical care units worldwide. Clinically, ARDS is defined by acute respiratory failure with severe hypoxemia and diffuse lung infiltrates. Mortality rate of ARDS (35\%-45\%) has remained relatively unchanged since 1994, despite recent advances in critical care and significant efforts achieved in the basic research and clinical trials of ARDS [1]

There are two recognized pathogenic mechanisms: Direct pulmonary injury (pulmonary ARDS) or indirect injury of the lung from acute systemic inflammation (extrapulmonary ARDS). The common causes of pulmonary ARDS are pneumonia, aspiration of orogastric contents, and drowning, whereas the main causes of extrapulmonary ARDS are extrapulmonary sepsis, acute pancreatitis, massive blood transfusion, polytrauma, and hemorrhagic shock [2].

Pulmonary and extrapulmonary ARDS subgroups have been found to have different pathophysiology, epidemiologic, and radiologic pictures. Pulmonary ARDS results from a direct infective or inflammatory (e.g., indrowing) insult to the lung parenchyma results in disruption of the alveolar epithelium, alterations of the type I and II epithelial cells and neutrophils, and exudation of the intraalveolar space with fibrin and collagen with minimal interstitial edema. On the other hand, extrapulmonary ARDS results from a systemic insult lead-

\section{Abbreviations:}

ARDS : : Acute Respiratory Distress Syndrome.

PEEP : Positive End Expiratory Pressure.

ALI : Acute Lung Injury.

APACH 111 : Acute physiologic and chronic health evaluation. 
ing to widespread circulation of inflammatory cytokines, damage of pulmonary vascular endothelium with increased vascular permeability and interstitial edema [3].

Radiologically, pulmonary ARDS is characterized by an asymmetric mixture of areas of consolidation and ground-glass opacification while extrapulmonary ARDS demonstrates a predominantly symmetric and homogenous ground-glass infiltrates (interstitial edema) [4].

Clinically, these pathophysiologic alterations associated with both types of ARDS translate to differing responses to ventilation strategies (e.g., use of variable levels Positive End-Expiratory Pressure [PEEP], alveolar recruitment maneuvers, and prone positioning) [5]

Aim of the work: The aim of this work was to compare the clinical characteristics and outcomes between the two major ARDS subtypes; pulmonary and extrapulmonary ARDS.

\section{Patients and Methods}

The study included sixty (60) patients diagnosed as ARDS and admitted to the Intensive Care Unit at El-Hussein University Hospital from July 2014 to January 2016. ARDS was diagnosed according to the American-European Consensus Committee criteria for ARDS that defined ARDS as acute lung injury characterized by:

1- $\mathrm{PaO}_{2} / \mathrm{FiO}_{2} \leq 200 \mathrm{mmHg}$.

2- Bilateral infiltrates consistent with pulmonary edema.

3- No clinical evidence of left ventricular failure or, pulmonary artery occlusion pressure $\leq 18$ $\mathrm{mmHg}[6]$.

All patients were subdivided into two major groups; pulmonary and extrapulmonary ARDS groups according to the predisposing factor of ARDS whether direct (pulmonary) or indirect (exrapulmonary) lung injuries. Pulmonary ARDS group composed of 40 patients while extrapulmonary ARDS group composed of 20 patients, all above 18 years old.

\section{All patients will be subjected to the following:}

1- Full history taking (reported from the hospital or ICU admission sheet).

2- Complete clinical examination including both local and general examination.
3- Routine laboratory testing with certain emphasis on (complete blood picture, serum total bilirubin, serum albumin, liver enzymes, serum creatinine, serum sugar and ESR).

4- Chest X-ray.

5- Arterial blood gases analysis.

6- Echocardiography to exclude left sided heart failure.

7- Determination of APACHE III Score on admission to the ICU.

8- Confirming the diagnosis of ARDS based on the chest X-ray findings, ABG analysis and absence of left ventricular failure.

9- Determination of lung injury score.

10- Determination of associated significant comorbidities.

11-Determination of clinical outcome by detecting the following:

a- 28-d mortality.

b- 60-d mortality.

c- ICU length of stay.

d- ICU-free days.

e- Total ventilator days.

f- Ventilator-free days.

g- Successful extubation.

\section{Inclusion criteria:}

All patients fulfilling the criteria of ARDS admitted to the intensive care unit and aged more than 18 years were enrolled into the study.

\section{Exclusion criteria:}

Patients aged 18 years or younger and patients with combined risk factors for ARDS were excluded from this study.

\section{Statistical analysis:}

Statistical analysis was carried out using the SPSS computer package version 21.0 (SPSS Inc., Chicago, IL, USA). For descriptive statistics: The mean \pm SD were used for quantitative variables while the number and percentage were used for qualitative variables. Fischer's Exact Test (FET) was used to assess the differences in frequency of qualitative variables while Mann-Whitney U-test was applied to assess the differences in means of quantitative variables. The statistical methods were verified, assuming a significant level of $p<0.05$ and a highly significant level of $p<0.001$. 


\section{Results}

Table (1): Age distribution in pulmonary and extrapulmonary ARDS groups.

\begin{tabular}{lcccc}
\hline Variable & $\begin{array}{c}\text { Pulmonary } \\
\text { ARDS group } \\
\text { No=40) } \\
\text { Mean } \pm \text { SD }\end{array}$ & $\begin{array}{c}\text { Extrapulmonary } \\
\text { ARDS group } \\
\text { (No=20) } \\
\text { Mean } \pm \text { SD }\end{array}$ & $\begin{array}{c}t- \\
\text { test }\end{array}$ & $\begin{array}{c}p \text { - } \\
\text { value }\end{array}$ \\
\hline Age & $50.2 \pm 10.5$ & $47.1 \pm 11.8$ & 0.948 & 0.347 \\
\hline
\end{tabular}

There is no significant difference between both groups in age distribution.

Table (2): Sex distribution in pulmonary and extrapulmonary ARDS groups.

\begin{tabular}{lcccc}
\hline Variable & $\begin{array}{c}\text { Pulmonary } \\
\text { ARDS group } \\
(\mathrm{No=40)} \\
(\%)\end{array}$ & $\begin{array}{c}\text { Extrapulmonary } \\
\text { ARDS group } \\
(\mathrm{No}=20) \\
(\%)\end{array}$ & $\begin{array}{c}\mathrm{F}- \\
\text { test }\end{array}$ & $\begin{array}{c}p \text { - } \\
\text { value }\end{array}$ \\
\hline Male sex & $18(45.0)$ & $15(75.0)$ & 4.8 & 0.032 \\
\hline
\end{tabular}

There is a significant increase in male sex in extrapulmonary than in pulmonary ARDS groups.

Table (3): Apachi III score values in pulmonary and extrapulmonary ARDS groups.

\begin{tabular}{lcccc}
\hline Variable & $\begin{array}{c}\text { Pulmonary } \\
\text { ARDS group } \\
(\mathrm{No}=40) \\
\text { Mean } \pm \mathrm{SD}\end{array}$ & $\begin{array}{c}\text { Extrapulmonary } \\
\text { ARDS group } \\
(\mathrm{No}=20) \\
\text { Mean } \pm \mathrm{SD}\end{array}$ & $\begin{array}{c}t- \\
\text { test }\end{array}$ & $\begin{array}{c}p- \\
\text { value }\end{array}$ \\
\hline APACHI score & $66.9 \pm 13.3$ & $91.5 \pm 11.7$ & $7.2<0.001$ \\
\hline
\end{tabular}

There is a significant increase in Apachi III score in extrapulmonary than in pulmonary ARDS groups.

Table (4): Predisposing factors for ARDS in both groups.

\begin{tabular}{|c|c|c|c|c|}
\hline $\begin{array}{l}\text { Predisposing } \\
\text { factors }\end{array}$ & $\begin{array}{c}\text { Pulmonary } \\
\text { ARDS } \\
(\mathrm{No}=40) \\
(\%)\end{array}$ & $\begin{array}{c}\text { Extrapulmonary } \\
\text { ARDS } \\
(\mathrm{No}=20) \\
(\%)\end{array}$ & $\begin{array}{l}\text { F- } \\
\text { test }\end{array}$ & $\begin{array}{c}p- \\
\text { value }\end{array}$ \\
\hline $\begin{array}{l}\text { - Bacterial } \\
\text { pneumonia }\end{array}$ & $30(75.0)$ & $0(0.0)$ & 30 & $<0.001$ \\
\hline - Viral pneumonia & $4(10.0)$ & $0(0.0)$ & 2.1 & 0.291 \\
\hline $\begin{array}{l}\text { - Aspiration of } \\
\text { gastric contents }\end{array}$ & $4(10.0)$ & $0(0.0)$ & 2.1 & 0.291 \\
\hline $\begin{array}{l}\text { - Inhalation lung } \\
\text { injury }\end{array}$ & $2(5.0)$ & $0(0.0)$ & 2.03 & 0.897 \\
\hline - Trauma & $0(0.0)$ & $6(30.0)$ & 4.8 & 0.032 \\
\hline $\begin{array}{l}\text { - Multiple blood } \\
\text { transfusion }\end{array}$ & $0(0.0)$ & $10(50.0)$ & 24 & $<0.001$ \\
\hline $\begin{array}{l}\text { - Extrapulmonary } \\
\text { sepsis }\end{array}$ & $0(0.0)$ & $14(70.0)$ & 36.5 & $<0.001$ \\
\hline
\end{tabular}

Pneumonia (bacterial and viral) is the main predisposing factors for pulmonary ARDS while extrapulmonary sepsis and multiple blood transfu- sions are the main predisposing factors for extrapulmonary ARDS.

Table (5): Co-morbid conditions associated with pulmonary and extrapulmonary ARDS.

\begin{tabular}{|c|c|c|c|c|}
\hline $\begin{array}{l}\text { Co-morbid } \\
\text { conditions }\end{array}$ & $\begin{array}{c}\text { Pulmonary } \\
\text { ARDS group } \\
(\mathrm{No}=40) \\
(\%)\end{array}$ & $\begin{array}{l}\text { Extrapulmonar } \\
\text { ARDS grou } \\
(\mathrm{No}=20) \\
(\%)\end{array}$ & $\begin{array}{l}y \\
\text { F- } \\
\text { test }\end{array}$ & $\begin{array}{c}p- \\
\text { value }\end{array}$ \\
\hline Diabetes mellitus & $18(45.0)$ & $10(50.0)$ & 4.1 & 0.107 \\
\hline Renal failure & $2(5.0)$ & $0(0.0)$ & 1.03 & 0.548 \\
\hline Liver failure & $2(5.0)$ & $2(10.0)$ & 1.8 & 0.981 \\
\hline Metastatic cancer & $3(7.5)$ & $0(0.0)$ & 2.2 & 0.191 \\
\hline Post-operative & $2(5.0)$ & $8(40.0)$ & 12.6 & $<0.001$ \\
\hline
\end{tabular}

DM is the main comorbid condition associated with both pulmonary and extrapulmonary ARDS while post-operative status is the main comorbid condition for extrapulmonary ARDS.

Table (6): Complete blood picture in pulmonary and extrapulmonary ARDS groups.

\begin{tabular}{lccccc}
\hline CBC & $\begin{array}{c}\text { Pulmonary } \\
\text { ARDS group } \\
(\text { No=40) } \\
\text { Mean } \pm \text { SD }\end{array}$ & $\begin{array}{c}\text { Extrapulmonary } \\
\text { ARDS group } \\
(\text { No=20) } \\
\text { Mean } \pm \text { SD }\end{array}$ & $\begin{array}{c}t- \\
\text { test }\end{array}$ & $\begin{array}{c}p- \\
\text { value }\end{array}$ \\
\hline WBC & $12.5 \pm 2.2$ & $16.8 \pm 2.9$ & 5.8 & $<0.001$ \\
Hematocrit & $34.8 \pm 3.8$ & $28.7 \pm 2.7$ & 6.5 & $<0.001$ \\
Platelets & $208.8 \pm 58.9$ & $122.9 \pm 39.3$ & 5.9 & $<0.001$ \\
\hline
\end{tabular}

There is a significant increase in WBC in extrapulmonary ARDS and a significant decrease in hematocrit and platelets than in pulmonary ARDS.

Table (7): Liver and renal functions in pulmonary and extrapulmonary ARDS groups.

\begin{tabular}{lccccc}
\hline $\begin{array}{l}\text { Liver } \\
\text { and renal } \\
\text { functions }\end{array}$ & $\begin{array}{c}\text { Pulmonary } \\
\text { ARDS group } \\
(\mathrm{No}=40) \\
\text { Mean } \pm \mathrm{SD}\end{array}$ & $\begin{array}{c}\text { Extrapulmonary } \\
\text { ARDS group } \\
(\mathrm{No}=20) \\
\text { Mean } \pm \mathrm{SD}\end{array}$ & $\begin{array}{c}t^{-} \\
\text {test }\end{array}$ & $\begin{array}{c}p \text { - } \\
\text { value }\end{array}$ \\
\hline Serum albumin & $3.3 \pm 0.3$ & $2.7 \pm 0.5$ & 5.0 & $<0.001$ \\
Total bilirubin & $1.2 \pm 0.3$ & $1.8 \pm 0.6$ & 4.7 & $<0.001$ \\
Serum creatinine & $1.6 \pm 0.4$ & $2.2 \pm 0.7$ & 3.5 & $<0.001$ \\
\hline
\end{tabular}

There is a significant decrease in albumin and an increase in bilirubin and creatinine in extrapulmonary ARDS than in pulmonary ARDS groups.

Table (8): Arterial blood gases in pulmonary and extrapulmonary ARDS groups.

\begin{tabular}{lcccc}
\hline Variable & $\begin{array}{c}\text { Pulmonary } \\
\text { ARDS group } \\
(\mathrm{No}=40) \\
\text { Mean } \pm \mathrm{SD}\end{array}$ & $\begin{array}{c}\text { Extrapulmonary } \\
\text { ARDS group } \\
(\mathrm{No}=20) \\
\text { Mean } \pm \mathrm{SD}\end{array}$ & $\begin{array}{c}t- \\
\text { test }\end{array}$ & $\begin{array}{c}p \text { - } \\
\text { value }\end{array}$ \\
\hline $\mathrm{PH}$ & $7.36 \pm 0.05$ & $7.30 \pm 0.04$ & 4.4 & $<0.001$ \\
$\mathrm{PaCo} 2$ & $40.6 \pm 6.0$ & $37.7 \pm 6.2$ & 1.7 & 0.099 \\
$\mathrm{PaO}_{2} / \mathrm{Fio}_{2}$ & $125.7 \pm 24.9$ & $103.4 \pm 25.8$ & 3.8 & 0.031 \\
\hline
\end{tabular}


There is significant decrease in $\mathrm{PH}$ and $\mathrm{Pao}_{2} /$ $\mathrm{Fio}_{2}$ in extrapulmonary than in pulmonary ARDS groups.

Table (9): Lung injury score in pulmonary and extrapulmonary ARDS groups.

\begin{tabular}{lcccc}
\hline Variable & $\begin{array}{c}\text { Pulmonary } \\
\text { ARDS group } \\
(\mathrm{No}=40) \\
\text { Mean } \pm \mathrm{SD}\end{array}$ & $\begin{array}{c}\text { Extrapulmonary } \\
\text { ARDS group } \\
(\mathrm{No}=20) \\
\text { Mean } \pm \mathrm{SD}\end{array}$ & $\begin{array}{c}t \text { - } \\
\text { test }\end{array}$ & $\begin{array}{c}p \text { - } \\
\text { value }\end{array}$ \\
\hline Lung injury score & $2.69 \pm 0.4$ & $2.46 \pm 0.5$ & 1.90 .067 \\
\hline
\end{tabular}

There is no significant difference in lung injury score between pulmonary and extrapulmonary ARDS groups.

Table (10): Use of vasopressors in pulmonary and extrapulmonary ARDS groups.

\begin{tabular}{lcccc}
\hline \multirow{4}{*}{ Variable } & \multicolumn{3}{c}{ Pulmonary } & Extrapulmonary \\
& $\begin{array}{c}\text { ARDS group } \\
(\mathrm{No}=40) \\
(\%)\end{array}$ & $\begin{array}{c}\text { ARDS group } \\
(\mathrm{No}=20) \\
(\%)\end{array}$ & $\begin{array}{c}\text { F- } p \text { - } \\
\text { test value }\end{array}$ \\
\hline Use of vasopressors & $16(40.0)$ & $16(80.0)$ & 9.6 & 0.003 \\
\hline
\end{tabular}

Eighty percent of patients with extrapulmonary ARDS treated by vasopressors compared to forty percent in patients with pulmonary ARDS with a significant difference.

Table (11): Positive End Expiratory Pressure (PEEP) values in pulmonary and extrapulmonary ARDS groups.

\begin{tabular}{lcccc}
\hline Variable & $\begin{array}{c}\text { Pulmonary } \\
\text { ARDS group } \\
(\mathrm{No}=40) \\
(\%)\end{array}$ & $\begin{array}{c}\text { Extrapulmonary } \\
\text { ARDS group } \\
(\mathrm{No}=20) \\
(\%)\end{array}$ & $\begin{array}{c}\text { F- } \\
\text { test }\end{array}$ & $\begin{array}{c}p \text { - } \\
\text { value }\end{array}$ \\
\hline PEEP $\mathrm{mmHg}$ & $7.33 \pm 0.94$ & $10.33 \pm 0.04$ & 9.6 & 0.003 \\
\hline
\end{tabular}

Table (12): Clinical outcome in pulmonary and extrapulmonary ARDS groups.

\begin{tabular}{|c|c|c|c|c|}
\hline $\begin{array}{l}\text { Clinical outcome } \\
\text { variables }\end{array}$ & $\begin{array}{l}\text { Pulmonary } \\
\text { ARDS } \\
\text { group } \\
\text { No=40 }\end{array}$ & $\begin{array}{c}\text { Extra- } \\
\text { pulmonary } \\
\text { ARDS group } \\
\mathrm{No}=20\end{array}$ & $\begin{array}{l}t \text { or } \\
\text { FET } \\
\text { test }\end{array}$ & $\begin{array}{c}p- \\
\text { value }\end{array}$ \\
\hline $\begin{array}{l}\cdot \text { ICU LOS } \\
(\text { Mean } \pm \text { SD) }\end{array}$ & $13.8 \pm 4.0$ & $20.9 \pm 6.1$ & 4.7 & $<0.001$ \\
\hline $\begin{array}{l}- \text { ICU free days } \\
(\text { Mean } \pm \text { SD) }\end{array}$ & $10.8 \pm 6.1$ & $7.2 \pm 3.6$ & 2.7 & 0.010 \\
\hline $\begin{array}{l}\text { Total ventilator } \\
\text { days }(\text { Mean } \pm \text { SD) }\end{array}$ & $12.01 \pm 3.0$ & $14.7 \pm 4.7$ & 2.2 & 0.035 \\
\hline $\begin{array}{l}\text { Ventilator free } \\
\text { days }(\text { Mean } \pm \text { SD) }\end{array}$ & $12.4 \pm 6.7$ & $8.7 \pm 4.4$ & 2.5 & 0.014 \\
\hline $\begin{array}{l}\text { - Successful } \\
\text { extubation (\%) }\end{array}$ & $30(75.0)$ & $5 \quad(25.0)$ & 13.7 & $<0.001$ \\
\hline $\begin{array}{l}\cdot(28 \mathrm{~d}) \text { mortality } \\
\text { rate }(\%)\end{array}$ & $8 \quad(20.0)$ & $13(65.0)$ & 10.8 & 0.002 \\
\hline $\begin{array}{l}\cdot(60 \mathrm{~d}) \text { mortality } \\
\text { rate }(\%)\end{array}$ & $10(25.0)$ & $15(75.0)$ & 13.7 & $<0.001$ \\
\hline
\end{tabular}

There is a significant increase in PEEP in patients with extrapulmonary ARDS than in patients with pulmonary ARDS groups.

There is significant increase in ICU LOS and total ventilator days in extrapulmonary ARDS with significant decrease in ICU free days and ventilator free days. Successful extubation is more in pulmonary ARDS. Mortality was $75 \%$ at 60 day in extrapulmonary ARDS compared to $25 \%$ in pulmonary ARDS with a significant difference.

\section{Discussion}

ARDS is a clinical syndrome associated with complex interactions among the predisposing conditions, associated comorbidities, and genetic determinants. This heterogeneity results in complexity and uncertainty in the study of this syndrome, [7] It is possible that clinical trials have not reported an effective treatment that could be generalized, because a therapy that benefits one group may not benefit another group [8].

Therefore, a better classification of ARDS subgroups is critical in the future research and management of ARDS. In 1998, it was the first study that described the differences of underlying pathology, pulmonary mechanics, and response to mechanical ventilation specific modes between pulmonary and extrapulmonary ARDS [9].

In the present study, we classified patients with ARDS according to the type of lung injury whether direct or indirect into pulmonary ARDS (direct lung injury) and extrapulmonary ARDS (indirect lung injury), aiming to exhibit any difference in the clinical characteristics and outcome. Pulmonary ARDS group comprised 40 patients; 18 males and 22 females with mean age of 50.2 years while extrapulmonary ARDS group comprised 20 patients; 15 males and 5 females with mean age of 47.1 years. Statistically, there was no difference between groups in age while there was a significant increase in male sex among patients with extrapulmonary ARDS compared to pulmonary ARDS groups.

Apachi III score was significantly increased in extrapulmonary than in pulmonary ARDS groups. Pneumonia (bacterial and viral) was the main predisposing factors for pulmonary ARDS while extrapulmonary sepsis, multiple blood transfusion and polytrauma were the main predisposing factors for extrapulmonary ARDS.

In the study of Gattinon et al., 1998, twenty one patients with ARDS were examined. Twelve 
patients had pulmonary ARDS while nine patients had extrapulmonary ARDS. The study reported no difference between both groups in sex and Apachi III score while age was lower in patients with pulmonary ARDS. Polytrauma and peritonitis were the main predisposing factors for extrapulmonary ARDS while pneumonia was the main predisposing factor for pulmonary ARDS [9].

In terms of systemic effects of ARDS and severity of organ dysfunction; the present study revealed more deterioration in liver and renal functions and disturbance of blood picture in patients with extrapulmonary ARDS than in patients with pulmonary ARDS.

Understanding the pathophysiology of pulmonary and extrapulmonary ARDS explains these results. In extrapulmonary ARDS, the triggering mediators released from injured epithelium circulate in blood to reach and injure the pulmonary capillary endothelium, with an increase of vascular permeability and interstitial oedema. This intravascular release of mediators like IL 1 and tumor necrosis factor cause its systemic effects on liver, kidney and blood cell components in addition to lungs. In pulmonary ARDS, there is direct injury to alveolar epithelium by the pre-existent local lung pathology is more relevant than systemic effects [10].

Godman et al., 1999 studied radiological, clinical and functional correlation between pulmonary and extrapulmonary ARDS patients. They reported that organ dysfunction was worse in patients with extrapulmonary ARDS than in patients with pulmonary ARDS [11]

In terms of response to given treatment, eighty percent of patients with extrapulmonary ARDS treated by vasopressors compared to forty percent in patients with pulmonary ARDS with a significant difference. PEEP required was high in extrapulmonary ARDS than in pulmonary ARDS. Extrapulmonary sepsis, the main indication for use of vasopressors, represented the major percentage of extrapulmonary ARDS patients.

Patients with extrapulmonary ARDS have decreased chest wall compliance and increased chest wall elastance (due to chest wall edema and increased abdominal pressure in some cases) [12] Application of PEEP in patients with pulmonary ARDS (i.e., an opposing force on the intraabdominal pressure) will result in the improvement in respiratory system compliance and increase lung recruitment $[13,14]$
On the other hand, patients with pulmonary ARDS have decreased lung compliance, and less ventilator pressures are transmitted to the pleura resulting in increase in transpulmonary pressures and lung overdistension. In this category of patients, application of PEEP leads to alveolar overstretching and volutrauma. This response to PEEP is also owing to a prevalence of consolidation in pulmonary ARDS as opposed to the prevalence of interstitial edema and alveolar collapse in extrapulmonary ARDS [12].

This is the main explanation for different response to PEEP between pulmonary and extrapulmonary ARDS patients. Similar results were obtained by Pelosi et al., 2011 and Pelosi et al., 1995 in their studies $[15,16]$

Patients with extrapulmonary ARDS had worse clinical outcomes than those with pulmonary ARDS, with significantly higher 28 -day (65\% vs. $20 \% ; p=.0 .002)$ and 60 -day (75\% vs. $25 \% ; p<$ $0.001)$ mortality rates, with fewer ICU-free days $(p=0.010)$ and ventilator-free days $(p=0.014)$, and lower successful extubation rates ( $25 \%$ vs. $75 \%$; $p=0.001$ ). In Gattioni et al., 1998, clinical outcome was determined using mortality rate and ICU stays days that were indifferent between pulmonary and extrapulmonary ARDS. Small number of patients included in the study of Gattioni et al., explains the different results [9].

Luo et al., 2017, studied clinical predictors of hospital mortality in both pulmonary and extrapulmonary ARDS. While the total hospital stay days were longer in extrapulmonary ARDS, the mortality rate was indifferent between both types of ARDS [17].

Agarwal et al., 2006, have studied the etiology and clinical outcomes of 180 patients with ARDS in intensive care unit in North India. At admission, while the patients with extrapulmonary ARDS were sicker than the patients with pulmonary ARDS, there was no difference between the two groups in development of new organ dysfunction or failure. The hospital mortality rate in pulmonary ARDS was $43.1 \%$ while in extrapulmonary ARDS, the mortality rate was $57.9 \%$ with no significant difference; $p=0.06$ ) [18].

In the present study, the deterioration in systemic organs that was more relevant in extrapulmonary ARDS may explain the increased mortality in this category of ARDS patients.

Conclusion: Classification of ARDS according to the cause of lung injury as pulmonary and ex- 
trapulmonary is beneficial to provide specific treatments and to predict prognosis and outcome. Patients with extrapulmonary ARDS have advanced organ dysfunction and better treated with vasopressors and high PEEP. Patients with pulmonary ARDS suffer from a lesser degree of organ dysfunction and better treated with protective low PEEP levels.

Recommendation: Proper assessment of ARDS patients at admission and intend to subdivide them into pulmonary and extrapulmonary categories. This sub classification will provide a greater help in treatment and prediction of outcome.

\section{Financial support and sponsorship:}

Nil.

\section{Conflicts of interest:}

None declared.

\section{References}

1- PHUA J., BADIA J.R., ADHIKARI N.K., et al.: Has mortality from acute respiratory distress syndrome decreased over time? A systematic review. Am. J. Respir. Crit. Care Med., 179 (3): 220-7, 2009.

2- LUO L., SHAVER C.M., ZHAO Z., et al.: Clinical predictors of hospital mortality differ between direct and indirect ARDS. Chest, 151: 755-63, 2017.

3- PELOSI P., D'ONOFRIO D., CHIUMELLO D., et al. Pulmonary and extrapulmonary acute respiratory distress syndromes are different. Eur. Respir. J. Suppl., 42: 48s$56 \mathrm{~s}, 2003$.

4- MÜLLER-LEISSE C., KLOSTERHALFEN B., HAUPTMANN S., et al.: Computed tomography and histologic results in the early stages of endotoxininjured pig lungs as a model for adult respiratory distress syndrome. Invest. Radiol., 28: 39-45, 1993.

5- THILLE A.W., RICHARD J.C., MAGGIORE S.M., et al.: Alveolar recruitment in pulmonary and extrapulmonary acute respiratory distress syndrome: Comparison using pressure-volume curve or static compliance. Anesthesiology, 106: 212-7, 2007.

6- BERNARD G.R., ARTIGAS A., BRIGHAM K.L., et al.: The American-European Consensus Conference on ARDS Defi-nitions, mechanisms, relevant outcomes, and clinical trial coordination. Am. J. Respir. Crit. Care Med., 149 (3 Pt 1): 818-24, 1994.
7- MATTHAY M.A., ZIMMERMAN G.A., ESMON C., et al.: Future research directions in acute lung injury: Summary of a National Heart, Lung, and Blood Institute working group. Am. J. Respir. Crit. Care Med., 167 (7): $1027-35,2003$.

8- PHUA J., STEWART T.E. and FERGUSON N.D.: Acute respiratory distress syndrome 40 years later: Time to revisit its definition. Crit. Care Med., 36 (10): 2912-21, 2008.

9- GATTINONI L., PELOSI P., SUTER P.M., PEDOTO A., VERCESI P. and LISSONI A.: Acute respiratory distress syndrome caused by pulmonary and extrapulmonary disease. Different syndromes? Am. J. Respir. Crit. Care Med., 158 (1): 3-11, 1998.

10- AGARWAL R., AGGARWAL A.N., GUPTA D., et al.: Etiology and outcomes of pulmonary and extrapulmonary acute lung injury/ARDS in a respiratory ICU in North India. Chest, 130: 724-9, 2006.

11- GOODMAN L.R., FUMAGALLI R., TAGLIABUE P., et al.: Adult respiratory distress syndrome due to pulmonary and extrapulmonary causes: CT, clinical, and functional correlations. Radiology, 213: 545-52, 1999.

12- GATTINONI L., CHIUMELLO D., CARLESSO E., et al.: Bench-to bedside review: Chest wall elastance in acute lung injury/acute respiratory distress syndrome patients. Crit. Care, 8: 350-5, 2004.

13- PELOSI P., LUECKE T. and ROCCO P.R.: Chest wall mechanics and abdominal pressure during general anaesthesia in normal and obese individuals and in acute lung injury. Curr. Opin. Crit. Care, 17: 72-9, 2011.

14- PELOSI P., CEREDA M., FOTI G., et al.: Alterations of lung and chest wall mechanics in patients with acute lung injury: Effects of positive endexpiratory pressure. Am. J. Respir. Crit. Care Med., 152: 531-7, 1995.

15- PELOSI P., LUECKE T. and ROCCO P.R.: Chest wall mechanics and abdominal pressure during general anaesthesia in normal and obese individuals and in acute lung injury. Curr. Opin. Crit. Care, 17: 72-9, 2011.

16- PELOSI P., CEREDA M., FOTI G., et al.: Alterations of lung and chest wall mechanics in patients with acute lung injury: Effects of positive endexpiratory pressure. Am. J. Respir. Crit. Care Med., 152: 531-7, 1995.

17- LUO L., SHAVER C.M., ZHAO Z., et al.: Clinical predictors of hospital mortality differ between direct and indirect ARDS. Chest, 151: 755-63, 2017.

18- AGARWAL R., AGGARWAL A.N., GUPTA D., et al.: Etiology and outcomes of pulmonary and extrapulmonary acute lung injury/ARDS in a respiratory ICU in North India. Chest, 130: 724-9, 2006. 


\section{متلازمة الضائقة التنفسية الحادة الناتجة من آمراض رئوية وخارج الرئة. الخصائص والنتائج السريرية من آمرادية}

الخلفية: متلازمة الضائقة التففسية الحادة هي متلازمة سريرية تتميز بنقص التاكسج بسبب الآمراض الرئوية الإلتهابية المباشرة آو غير

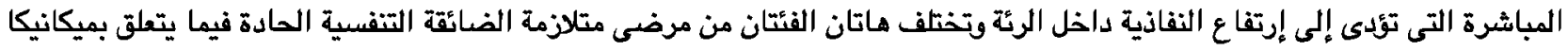

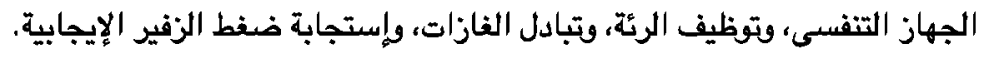

الهدف من الدراسة: مقارنة الخصائص والنتائج السريرية بين النوعين الفرعيين الرئيسيين من متلازمة الضائقة التنفسية الحادة، الرئوى وغير الرئوى.

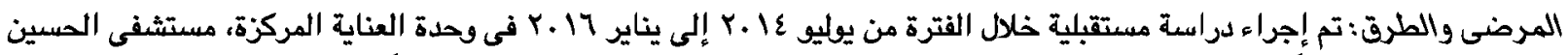

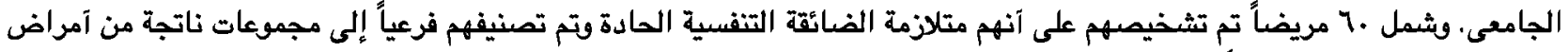
رئوية وآمراض خارج الرئة وفقاً لسبب إصابة الرئة. تمت مقارنة المجموعتين فيما يتعلق بالسمات السريرية والإستجابة العلاج والنتائج السريرية. النتائج: المرضى الذين يعانون من متلازمة الضائقة التنفسية الحادة ناتجة من آسباب خارج الرئة إستجابة آفضل لمستويات مرتفعة من

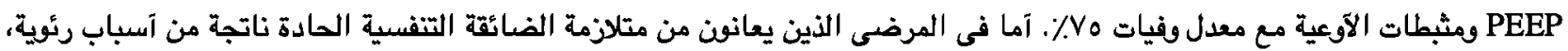

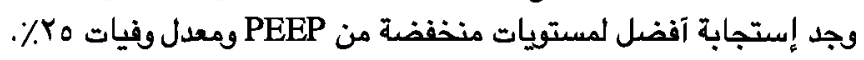

الخلاصة : إن تقسيم متلازمة الضـائقة التففية الحادة إلى فئات رئوية وخارج الرئة له تآثير جدير على كل من العلاج والنتائج السريرية.

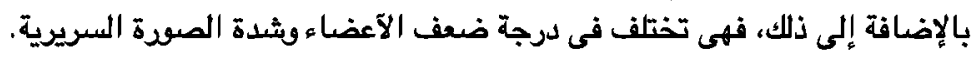

التوصية: التقييم السليم للمرضى الذين يعانون من متلازمة الضعائقة التنفسية الحادة عند القبول لوضعهم ضمن فئة رئيسية سواء متلازمة

الضعائقة التففية الحادة الرئوية آوخارج الرئة. سيسيساعد هذا التصنيف البسيط الطبيب على إتخاذ قرار بثآن العلاج والمتابعة. 